\title{
Determination of Nutritional Composition and Effect of Various Storage Conditions on the Vitamin C Content in Garcinia Dulcis, in Fresh and Dry Form
}

\author{
Mansoor Abdul Hamid, Pang Kia Wen, Hasmadi Mamat and Shalawati@ Salwa Ibrahim \\ School of Food Science \& Nutrition, Universiti Malaysia Sabah, Jalan UMS, 88400 Kota Kinabalu, Sabah, Malaysia \\ E-mail:mah_chotey@ums.edu.my,idamsah@ums.edu.my,carmen@ums.edu.my,salwa@ums.edu.my
}

\begin{abstract}
This study was carried to determine the nutritional properties of fresh Garcinia dulcis fruit, an indigenous fruit growth in Sabah, included proximate content of moisture, ash, crude protein, crude fat, crude fibre, total dietary fibre and total carbohydrate, vitamin $C$ as well as several minerals content. The effect of different drying techniques and storage conditions on the vitamin $C$ content in dried Garcinia dulcis was investigated. The fruit slices were separated into four groups which subjected to four drying techniques, which were sun drying, hot air drying at $50^{\circ} \mathrm{C}$ and $60^{\circ} \mathrm{C}$ and vacuum drying, and dried to the moisture content of $16 \pm 1 \%$. After drying, the sample was subjected to four storage conditions, which were dark and air-tight, dark and non-air-tight, light and air-tight and light and non-air-tight, and the vitamin $C$ content was analyzed for sample subjected to each condition once per 7 days of storage until 28 days of storage. From the analysis, the nutritional properties of fresh fruit with the content of moisture $(86.64 \pm 0.21 \%)$, ash $(0.68 \pm 0.01 \%)$, crude protein $(0.59 \pm 0.03 \%)$, crude fat $(0.40 \pm 0.02 \%)$, crude fibre $(1.89 \pm 0.04 \%)$, total carbohydrate $(9.80 \pm 0.18 \%)$ and total dietary fibre $(8.21 \pm 0.38 \%)$, vitamin $\mathrm{C}(6.88 \pm 0.33 \mathrm{mg} \mathrm{AA} / 100 \mathrm{~g}$ ww) and several minerals (potassium, $64.63 \pm 0.02 \mathrm{mg} / 100 \mathrm{~g}$ ww; phosphorus, $7.79 \pm 0.13 \mathrm{mg} / 100 \mathrm{~g}$ ww; calcium, $7.59 \pm 0.06 \mathrm{mg} / 100 \mathrm{~g}$ ww) were determined. The hot air drying at $50^{\circ} \mathrm{C}$ and vacuum drying retained highest amount of vitamin $\mathrm{C}$ among the four drying techniques just after the sample was dried. The best storage conditions for all the drying techniques were dark and air-tight conditions. It was found out that the drying technique interdependent to each other in order to retain the highest content of vitamin $\mathrm{C}$ in dried Garcinia dulcis sample for a longer period of time.
\end{abstract}

Keywords - Nutritional properties; Garcinia dulcis; vitamin C; drying technique; storage condition.

\section{INTRODUCTION}

Garcinia is a pan-tropical genus that belongs to the family Clusiaceae (Guttiferae) which contains about 35 genera and up to 800 species [1]. Among the 800 species, there are approximately 28 species that can be found in Malaysia, such as mangosteen (Garcinia mangostana) and asam gelugor (Garcinia atroviridus) [1]. In Malaysia, the genus Garcinia is best known as a genus of fruit trees that provide palatable fresh fruit pulp and fruit peel that acts as tamarind slices and add in acid flavour in local dishes. As Malaysia has a rich diversity of Garcinia species, many indigenous Garcinia species that may contain high nutritional values and bioactive compounds are still underutilized due to lack of popularity among the local citizen as most of these species have too acidic fruit pulp, lack of information on nutritional compositions and physical qualities and the lack of promotional activities for these species [2]. In Sabah, one of the underutilized Garcinia species is Garcinia dulcis.
Garcinia dulcis fruit is normally known as mundu fruit among the local citizen in Sabah [3]. This orange-coloured mundu fruit has watery acid pulp which is very sour and thus, the fruit pulp is seldom consumed in fresh form by the consumers. It is more often used in cooking curry cuisine among the local communities to give acid-sour flavour to the cuisine [4]. In Thailand, this fruit is reported that it is high in phosphorous and carbohydrate content. Besides that, the crushed extract of this fruit is used as a relief expectorant for cough and scurvy. Other than fruits, the other part of the plant, such as root and bark, are also used for traditional ethnomedical uses in several Southeast Asian countries. However, the information on nutritional composition of Garcinia dulcis fruit natively growth in Sabah is limited. With the limited information on its nutritional composition, limited analyses and product development have been done on Garcinia dulcis fruit. Thus, it is underutilized among the local citizen in Sabah.

As Garcinia dulcis and other Garcinia species normally have only one fruiting season throughout the year, drying is 
the most common preservative method used in domestic market [5]. However, drying could be an important factor affecting the nutritional values of fruit, especially vitamin $\mathrm{C}$ content as it is the least stable nutritive compound in fruits ([6], [7]). Besides, the storage conditions, such as exposure to light and oxygen, will affect the vitamin $\mathrm{C}$ retention rate in various types of fruit ([8], [9]). Thus, besides determination of the nutritional composition of fresh Garcinia dulcis fruit, the suitability of several drying techniques and the changes in the vitamin $\mathrm{C}$ content of dry Garcinia dulcis fruit slices with different storage conditions was investigated.

\section{Methodology AND SAMPLES}

\section{A. Chemicals}

Kjeltabs Copper 3.5; 95\% concentrated sulphuric acid; petroleum ether 30-60; sodium hydroxide; boric acid; bromocresol green indicator solution; methyl red indicator solution; dipotassium phosphate; 95\% concentrated hydrochloride acids; $\alpha$-amylase enzyme; protease enzyme; amyloglucosidase enzyme; 95\% ethanol; acetone; ascorbic acid standard; metaphosphoric acid; sodium acetate; glacial acetic acid; sodium 2,6-dichloroindophenolate, DCPI; 40\% concentrated nitric acid; ammonium molybdate; ammonium vanadate; potassium, calcium, magnesium sodium, iron, zinc and copper standard; potassium dihydrogen phosphate. All the chemicals and reagents used are of analytical grade. The standard solution for ascorbic acid was purchased from Labjax Chemical while the standard solution for potassium, phosphorus, calcium, magnesium, sodium, iron, zinc and copper were purchased from Merck. The water used in preparing the standard solutions for ascorbic acid and these minerals were deionized water with $18 \mathrm{~m} \Omega / \mathrm{cm}$ resistivity.

\section{B. Sample Preparation}

The fresh mundu fruits, Garcinia dulcis, were collected from Lagud Seberang Agricultural Research Station in Tenom, Sabah. Around $10 \mathrm{~kg}$ of fully ripe fruits that was fully yellowish-orange in colour and unbroken were chosen randomly. The maturity and quality of fruits were examined by the research officials in Lagud Seberang Agricultural Research Station. Then, the fruits were packed and transported back to the laboratory. The fruits were drained thoroughly under running tap water and wiped dry. Each fruit was cut into half and the fruit seeds were removed. The fruit pulp with peel was sliced into flat slabs, where $200 \mathrm{~g}$ of fresh fruit slices were blended using an electric blender, packed into tight container and stored at $-20^{\circ} \mathrm{C}$ in freezer before further analysis was conducted. The remaining fresh fruit slices were kept in $4^{\circ} \mathrm{C}$ prior to drying that was carried out within 24 hours.

Sun drying was achieved by spreading samples on aluminium tray and putting them under the protection of net, whereas, hot air drying was performed in the electric cabinet dryer with the temperature set at $50^{\circ} \mathrm{C}$ and $60^{\circ} \mathrm{C}$. Fresh samples were put on the aluminium tray and were dried to reach the desired moisture content. The remaining group of fresh sample was dried by using vacuum oven under vacuum condition and the temperature of the oven was set at $50^{\circ} \mathrm{C}$ ([5], [10]). For each group of sample, the final moisture content was determined by moisture analyzer. After they were dried to the desired moisture content, the dried fruit slices were ground in using an electric dry blender, kept in tight containers and stored at $4{ }^{\circ} \mathrm{C}$ in refrigerator prior to sample packaging.

TABLE 1: TYPES OF DRYING TECHNIQUE USED IN DRYING FRUIT SAMPLE, THEIR DRYING PARAMETERS AND FINAL MOISTURE CONTENT IN DRIED SAMPLE

\begin{tabular}{cccc}
\hline $\begin{array}{c}\text { Drying } \\
\text { technique }\end{array}$ & $\begin{array}{c}\text { Drying } \\
\text { temperature } \\
\left({ }^{\circ} \mathrm{C}\right)\end{array}$ & $\begin{array}{c}\text { Drying } \\
\text { duration }\end{array}$ & $\begin{array}{c}\text { Moisture } \\
\text { content }(\%)\end{array}$ \\
\hline $\begin{array}{c}\text { Sun dry } \\
\text { Hot air dry }\end{array}$ & $51 \pm 3$ & 6 days & $16.32 \pm 0.43$ \\
Hot air dry & $60 \pm 1$ & 50 hours & $15.76 \pm 0.24$ \\
Vacuum dry & $50 \pm 1$ & 18 hours & $15.32 \pm 0.13$ \\
\hline
\end{tabular}

The ground, dried sample that was dried using four different drying techniques were separated, packaged and stored in four different storage conditions, which were dark and air-tight, dark and non-air-tight, light and air-tight and light and non-air-tight conditions for five storage durations, which were 0 day, 7 days, 14 days, 21 days and 28 days of storage duration ([7], [9]). For air-tight storage, one of the samples in air-tight zipper bag was put in air-tight container that had been wrapped with aluminium foil and then stored in dark condition, whereas the remaining air-tight zipper bag was put another air-tight container and put in the condition where the sample will expose to light during the storage duration. This procedure was repeated for the two samples packed in non-air-tight condition. The containers were kept in their respective storage condition in ambient temperature, ranged from 20 to $25^{\circ} \mathrm{C}$ for each sample's storage duration. After the sample has been stored according to the storage duration, the sample was analyzed in triplicate for vitamin $\mathrm{C}$ analysis.

\section{Proximate Analysis}

Proximate analysis of moisture, ash, crude fibre and total dietary fibre on fresh sample was carried out based on [11] whereas, the total carbohydrate content calculation formula was based on formula used by (12). All the analyses were performed with three replicates.

\section{Vitamin C Analysis}

The vitamin $\mathrm{C}$ analysis was based on the procedures used by [13] with some modifications. As for the vitamin $\mathrm{C}$ content calculation formula (in $\mathrm{mg} \mathrm{AA} / \mathrm{g}$ of sample), the formula that was used in working manual prepared by [14] was used. Vitamin $\mathrm{C}$ was analyzed by using UV-Vis spectrophotometer (Perkin-Elmer Lambda 35, England), with the wavelength of detection was set at $520 \mathrm{~nm}$.

For vitamin $\mathrm{C}$ extraction, a total of $10.0 \pm 0.1 \mathrm{~g}$ of fresh sample or $1.0 \pm 0.1 \mathrm{~g}$ of dry sample was added to $25.0 \pm 0.1$ $\mathrm{ml}$ of extraction solution (5\% metaphosphoric acid, w/v). The mixture was homogenized and shakes on a vortex mixer at $2000 \mathrm{rpm}$ for 15 minutes. Then, the mixture was centrifuged at $4000 \mathrm{rpm}$ for 5 minutes. For the measurement of vitamin $\mathrm{C}$ of sample, a mixture of $1.0 \pm 0.1 \mathrm{ml}$ of supernatant, $1.0 \pm 0.1 \mathrm{ml}$ of acetate buffer solution and $8.0 \pm$ $0.1 \mathrm{ml}$ of DCPI solution were prepared. A blank solution was prepared for the sample by mixing $1.0 \pm 0.1 \mathrm{ml}$ of 
supernatant, $1.0 \pm 0.1 \mathrm{ml}$ of acetate buffer and $8.0 \pm 0.1 \mathrm{ml}$ of deionized water.

The instrument was adjusted to zero using blank solution and the absorbance of the solution that was made up of $1.0 \pm$ $0.1 \mathrm{ml}$ metaphosphoric acid, $1.0 \pm 0.1 \mathrm{ml}$ acetate buffer solution and $8.0 \pm 0.1 \mathrm{ml}$ DCPI solution was recorded as $\mathrm{L}_{1}$. Then, the absorbance of the tested standard solution or sample solution was recorded as $\mathrm{L}_{2}$. The wavelength $\mathrm{L}_{1}$ was the absorbance of all DCPI and $\mathrm{L}_{2}$ was the absorbance value of the remaining DCPI after reaction with ascorbic acid. The calibration graph was constructed by plotting the absorbance values $\left(\mathrm{L}_{1}-\mathrm{L}_{2}\right)$ versus concentration of standard ascorbic acid.

\section{E. Mineral Analysis}

The determination of mineral contents, included potassium, sodium, calcium, magnesium, iron, zinc and copper content, were carried out based on AOAC (Association of Official Analytical Chemists) analysis methods [15] with slight modification [16]. Phosphorus content in Garcinia dulcis fruit was determined by vanadate colorimetric method based on 1[7]. Before the mineral contents were analyzed, the sample was ashed using dry ashing method. Potassium, sodium, calcium, magnesium, iron, zinc and copper contents of the sample were determined by an atomic absorption spectrophotometer (AAS) (PerkinElmer AAnalyst 700, England). A series of standard solutions with concentrations from $0.2 \mathrm{ppm}$ to 1.0 ppm for potassium, sodium, calcium, magnesium, iron, zinc and copper were prepared and analyzed through AAS to obtain calibration curves.

As for phosphorus analysis, $2.0 \pm 0.1 \mathrm{ml}$ of ash solution was pipette into a $100 \mathrm{ml}$ volumetric flask. Then, it was diluted by $30.0 \pm 0.1 \mathrm{ml}$ of deionized water and $25.0 \pm 0.1$ $\mathrm{ml}$ of vanadate-molybdate reagent was added. Then, the solution was diluted by deionized water. Its absorbance was measured at $420 \mathrm{~nm}$ by using UV-Vis spectrophotometer (Perkin-Elmer Lambda 35, England). Sample blank was analyzed first before the analysis of sample. A series of standard solutions with concentrations from $0.25 \mathrm{mg} \mathrm{P} / 100$ $\mathrm{ml}$ to $1.0 \mathrm{mg} \mathrm{P} / 100 \mathrm{ml}$ were prepared and analyzed through UV-Vis spectrophotometer to obtain calibration curves. All the analyses were performed with triplicates.

\section{F. Statistical Analysis}

The data were statistically analyzed using SPSS version 17.0 (SPSS Inc., Chicago, Illinois, USA). Data were expressed as means \pm standard deviations of three replicate determinations.

\section{RESULTS AND DISCUSSION}

\section{A. Proximate analysis}

The proximate composition of Garcinia dulcis fruit was showed in Table 1. Based on the results, the most abundance composition in fresh Garcinia dulcis fruit was moisture content, followed by total carbohydrate content and crude fibre content, with crude fat content, was occupying the least portion in this fruit.

TABle 2: PRoXimate COMPOSITION OF GARCINIA DULCIS (\% SAMPLE WET WEIGHT BASIS)

\begin{tabular}{lc}
\hline Proximate composition & Content $(\%)$ \\
\hline Moisture & $86.64 \pm 0.21$ \\
Ash & $0.68 \pm 0.01$ \\
Crude protein & $0.59 \pm 0.03$ \\
Crude fat & $0.40 \pm 0.02$ \\
Crude fibre & $1.89 \pm 0.04$ \\
Total carbohydrate & $9.80 \pm 0.18$ \\
Total dietary fibre & $8.21 \pm 0.38$ \\
\hline Results are presented as mean value \pm standard deviation, $\mathrm{n}=9$
\end{tabular}

Based on the result obtained, Garcinia dulcis contained a total of $8.21 \pm 0.38 \%$ of total dietary fibre, which can be considered as source of total dietary fibre in solid food, as it had fulfilled the condition for nutritional claim based on Malaysia Food Act 1983 and Regulation .Due to the increasing awareness of the beneficial effects of dietary fibre toward health optimizing, food that is source of dietary fibre have been given more attention in analysing and product developing from the food that contain high total dietary fibre content.

\section{B. Vitamin C Analysis}

The vitamin $\mathrm{C}$ content in fresh Garcinia dulcis was determined as $6.88 \pm 0.33 \mathrm{mg} \mathrm{AA} / 100 \mathrm{~g}$ ww sample, which was higher than the vitamin $\mathrm{C}$ content $(5 \mathrm{mg} \mathrm{AA} / 100 \mathrm{~g} \mathrm{ww})$ of Garcinia dulcis Kurz. that was growth in Thailand [3]. This is probably due to the possible variation of ascorbic acid content between cultivars. It is reported that oranges that are cultivated in California and Florida have slightly different in ascorbic acid content, where cultivar in California have slightly higher ascorbic acid content than that of cultivar in Florida [18].

\section{Mineral Analysis}

The content of minerals in Garcinia dulcis fruit were showed in Table 2. The abundant mineral in Garcinia dulcis was potassium, followed by phosphorus and calcium. The abundance in potassium content in Garcinia dulcis fruit is following the general trend in fruits where potassium is usually the most abundant major minerals in fruits. For example, potassium is the most abundant element in mangosteen, which contains $45 \mathrm{mg} / 100 \mathrm{~g}$ edible portion according to [19].

TABLE 3: Mineral CONTENTS OF GARCINIA DUlCis (MG/100 G SAMPLE WET WEIGHT BASIS)

\begin{tabular}{lc}
\hline Mineral & Content $(\mathrm{mg} / 100 \mathrm{~g}$ sample ww) \\
\hline Potassium & $64.63 \pm 0.02$ \\
Phosphorus & $7.79 \pm 0.13$ \\
Calcium & $7.59 \pm 0.06$ \\
Magnesium & $3.85 \pm 0.00$ \\
Sodium & $1.60 \pm 0.01$ \\
Iron & $0.31 \pm 0.00$ \\
Zinc & $0.31 \pm 0.02$ \\
Copper & $0.02 \pm 0.00$ \\
\hline Results are presented as mean value \pm standard deviation, $\mathrm{n}=3$
\end{tabular}




\section{Effects of different drying techniques on vitamin $C$ content}

Based on the result obtained, hot air dried Garcinia dulcis sample at the temperature of $50^{\circ} \mathrm{C}$ and vacuum dried Garcinia dulcis sample showed significant high retention of vitamin $\mathrm{C}$ as compared between these four drying techniques $(p<0.05)$. Although vitamin $\mathrm{C}$ content in hot air dried sample at $60^{\circ} \mathrm{C}$ and sun dried sample had shown difference, the difference was not significant $(\mathrm{p}>0.05)$. The drying temperature used in hot air drying showed significant difference $(\mathrm{p}<0.05)$ in vitamin $\mathrm{C}$ retention, as hot air drying at $50^{\circ} \mathrm{C}$ retained approximately $29 \%$ more vitamin $\mathrm{C}$ as compared to the amount obtained from hot air dried sample at $60^{\circ} \mathrm{C}$.

TABLE 3: VITAMIN C CONTENT IN GARCINIA DULCIS AFTER SUBJECTED TO VARIOUS DRYING TECHNIQUES (DRY WEIGHT BASIS)

\begin{tabular}{lc}
\hline Drying techniques & $\begin{array}{c}\text { Vitamin C (mg AA/100g dry } \\
\text { weight) }\end{array}$ \\
\hline Fresh & $6.88 \pm 0.33^{*}$ \\
Sun drying & $12.47 \pm 0.65^{\mathrm{b}}$ \\
Hot air drying at $50^{\circ} \mathrm{C}$ & $19.59 \pm 1.32^{\mathrm{a}}$ \\
Hot air drying at $60^{\circ} \mathrm{C}$ & $15.14 \pm 1.03^{\mathrm{b}}$ \\
Vacuum drying & $19.07 \pm 1.13^{\mathrm{a}}$ \\
\hline *Value is in mg AA $/ 100 \mathrm{~g}$ wet weight for fresh sample. \\
Values are expressed as mean \pm standard deviation. $\mathrm{n}=3$. Values in \\
the same column with different letters are significantly different \\
$(\mathrm{p}<0.05)$.
\end{tabular}

The higher retention amount of vitamin $\mathrm{C}$ content in Garcinia dulcis fruit that was dried in hot air at $50^{\circ} \mathrm{C}$ than the sample dried in hot air drying at $60^{\circ} \mathrm{C}$ and sun drying was in agreement with [20], where nutrient losses during drying can be decreased by drying at a low temperature and shortening drying time. Although the drying temperature during sun drying process is lower than the drying temperature used in hot air oven drying at $50^{\circ} \mathrm{C}$, the excessive prolonged drying duration using sun drying create bigger impact on vitamin $\mathrm{C}$ retention. Furthermore, the direct exposure to oxygen and metal contaminants during sun drying period of sample increase further loss of vitamin $\mathrm{C}$ content in sample ([7], [21]).

Besides the drying time, the effectiveness of low drying temperature in vitamin $\mathrm{C}$ retention had been shown in this study between the hot air drying techniques at $50^{\circ} \mathrm{C}$ and $60^{\circ} \mathrm{C}$. An increase of the drying temperature increases the drying velocity; on the other hand, increase the rate of vitamin loss in sample [22]. For heat sensitive component like ascorbic acid, a low drying temperature is preferable although high drying temperature may inactivate ascorbate oxidase in order to prevent further degradation of vitamin $\mathrm{C}$ by heat ([6], [20], [23]. From the result obtained in this study, the amount of vitamin $\mathrm{C}$ that was retained after the sample is subjected to vacuum drying treatment at $50^{\circ} \mathrm{C}$ was higher than the amount retained in sun-dried sample. This is probably because of the difference in the degree of sample's exposure to oxygen during drying.

\section{E. Effects of different storage conditions on vitamin $C$ content}

The results obtained in the study on the effect of different storage conditions, namely dark versus light and air-tight versus non-air-tight storage conditions, on vitamin $\mathrm{C}$ content in Garcinia dulcis sample after the sample had been dried under sun drying, hot air drying at $50^{\circ} \mathrm{C}$ and $60^{\circ} \mathrm{C}$ and vacuum drying techniques, was analysed, summarized and presented in the Figure 1, 2, 3 and 4.

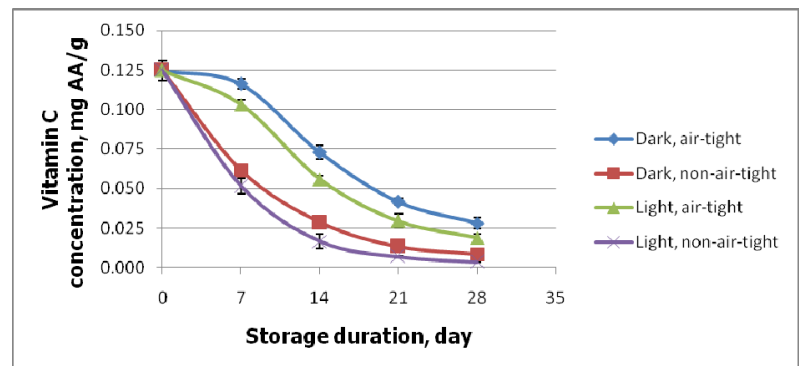

Figure 1: The vitamin $\mathrm{C}$ content in sun-dried sample kept in different storage conditions at different storage duration

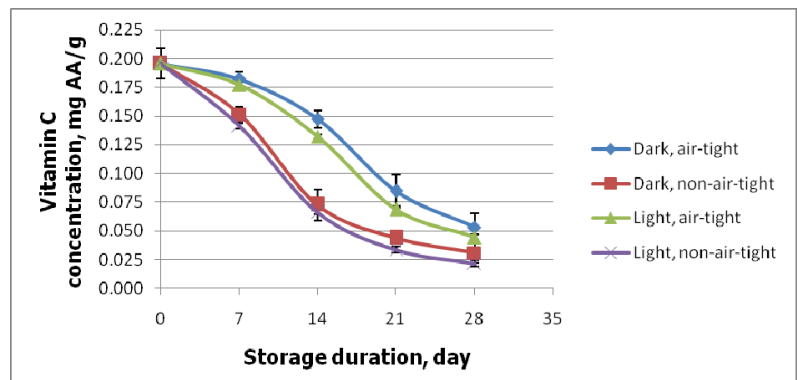

Figure 2: The vitamin $\mathrm{C}$ content in hot air-dried sample at $50^{\circ} \mathrm{C}$ kept in different storage conditions at particular storage duration

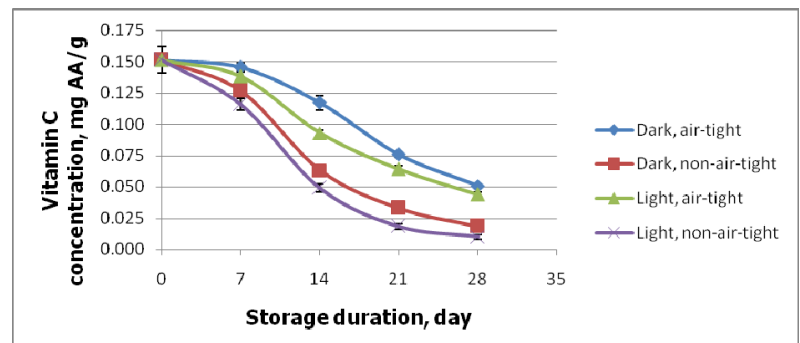

Figure 3: The vitamin $\mathrm{C}$ content in hot air-dried sample at $60^{\circ} \mathrm{C}$ kept in different storage conditions at particular storage duration

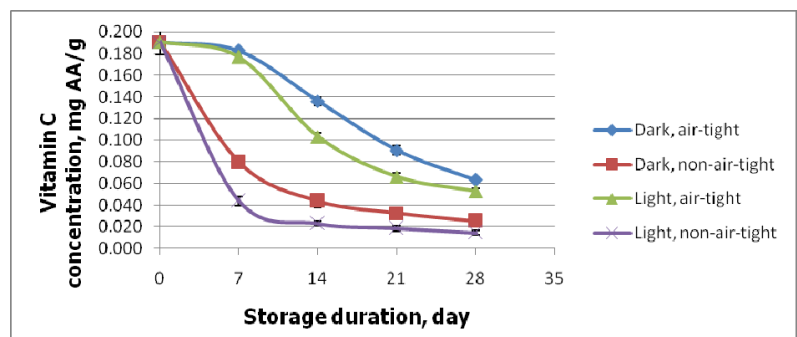

Figure 4: The vitamin C content in vacuum-dried sample that were kept in different storage conditions at particular storage durations

Based on the trends that had been observed in Figure 1, 2, 3 and 4 , overall, there were significantly sharp decreases in vitamin $\mathrm{C}$ content for each of the storage conditions, namely dark and air-tight, dark and non-air-tight, light and air-tight and light and non-air-tight condition, from 0 day to 28 days 
of storage $(p<0.05)$. This is due to the high susceptibly of ascorbic acid toward chemical and enzymatic oxidations during sample preparation, drying and storage. Besides the overall decreasing trend, there were significant differences existed between vitamin $\mathrm{C}$ content in sample that was kept in air-tight condition and sample that was kept in non-air-tight condition $(\mathrm{p}<0.05)$. The low oxygen content storage condition slows down the oxidation process and thus retains more vitamin C for a longer period of time [24].

Besides the occurrence of significant differences in vitamin $\mathrm{C}$ deterioration between sample that were kept in air-tight and non-air-tight, there were significant differences between vitamin $\mathrm{C}$ retention in sample that was stored in dark and light condition $(p<0.05)$, where the total vitamin $C$ retention is higher in the dark conditioned sample than the light conditioned sample. Similar trend was observed from the non-air-tight conditioned samples, where the range for dark, non-air-tight conditioned sample was bigger than the range for light, non-air-tight conditioned sample within 7 day to 28 days of storage. This is probably due to the generation of UV-light inducing oxygen free radicals, superoxide anion and singlet oxygen that oxidized ascorbic acid during the exposure of light ([25], [26]).

Besides the similarities of these trends stated above, there were some differences between the trends for sun dried, hot air dried and vacuum dried sample. First of all, there was difference in the trend of vitamin $\mathrm{C}$ loss in the condition of non-air-tight condition for the hot air dried sample as compared to non-air-tight conditioned sun dried sample, where the initiate loss in hot air dried sample was lower, followed by sharp decrease in the second weeks and following week of storage. This is difference from the nonair-tight sun dried sample where the initiate loss was a sharp decrease. This could be due to the adaptation period to stabilize the chemical constituents' equilibrium [24].

Besides, the decrease in vitamin $\mathrm{C}$ content at the first week of storage for vacuum-dried sample that were kept in non-air-tight condition, despite of the exposure or nonexposure to light, is significantly sharp as compared to the trends in the samples that undergone sun drying and hot air drying. This is probably due to the sudden increase in partial pressure of dissolved oxygen around the sample during storage, which is favourable toward vitamin $\mathrm{C}$ deterioration ([27], [28] ,[24], [29]).

Other than the differences between the trends of samples dried from different drying techniques, differences exist between vitamin $\mathrm{C}$ content in sample dried in $50^{\circ} \mathrm{C}$ and $60^{\circ} \mathrm{C}$. One of the differences is that the total loss in vitamin $\mathrm{C}$ of hot air dried sample at $60^{\circ} \mathrm{C}$ for 28 days of storage was lower to the total loss of hot air dried sample at $50^{\circ} \mathrm{C}$ for samples that were kept in ait-tight condition although the initiate vitamin $\mathrm{C}$ content just after drying was higher for hot air dried sample at $50^{\circ} \mathrm{C}$. These differences are probably due to the nearly deactivation of ascorbate oxidase after the sample was subjected to hot air drying at $60^{\circ} \mathrm{C}$ [24].

\section{CONCLUSIONS}

For all the drying techniques that had been used, the best storage condition based on the vitamin $\mathrm{C}$ retention at the 28 days of storage duration was the dark and air-tight condition.
Whereas, the worst storage condition for all the drying techniques was light and non-air-tight storage condition. Besides, hot air drying at the temperature of $60^{\circ} \mathrm{C}$ had the highest percentage of vitamin $\mathrm{C}$ retention at the 28 days of storage duration, followed by vacuum drying, hot air drying at $50^{\circ} \mathrm{C}$ and sun drying retained the least vitamin $\mathrm{C}$ content at the 28 days storage duration for the best storage condition.

\section{REFERENCES}

[1] Osman, B.M. and Milan, R.A. 2006. Mangosteen - Garcinia mangostana. Southampton Centre for Underutilised Crops. UK: University of Southampton.

[2] Ikram, E.H.K., Khoo, H.E., Jalil, A.M.M., Ismail, A., Idris, S., Azlan, A., Nazri, H.S.M. 2009. Antioxidant capacity and total phenolic content of Malaysian underutilized fruits. Journal of Food Composition and Analysis. 22(5):388-393.

[3] Subhadrabandhu, S. 2001. Under-utilized tropical fruits of Thailand pp:34-35. Thailand: Food and Agriculture Organization of the United Nations, Regional Office for Asia and the Pacific. Rap Publication: 2001/26.

[4] Wong, W.W.W., Chong, T.C., Tananak, J., Ramba, H. and Kalitu, N. 2007. Fruits of Sabah, Volume 1. pp:71-73. Sabah: Department of Agriculture.

[5] Gögüş, F., Özel, M.Z. and Lewis, A.C. 2007. The effect of various drying techniques on apricot volatiles analysed using direct thermal desorption-GC-TOF/MS. Talanta. 73:321-325.

[6] Chan, J.C.-C., Cheung, P.C.-K. and Ang, P.O. 1997. Comparative studies on the effect of three drying methods on the nutritional composition of seaweed Sargassum hemiphyllum (Turn.) C. Ag. J. Agric. Food Chem. 45:3056-3059.

[7] Ajibola, V.O., Babatunde, O.A. and Suleiman, S. 2009. The effect of storage method on the vitamin $\mathrm{C}$ content in some tropical fruit juices. Trends in Applied Sciences Research. 4(2):79-84.

[8] Lee, S.K. and Kader, A.A. 2000. Preharvest and postharvest factors influencing vitamin $\mathrm{C}$ content of horticultural crops. Postharvest Biology and Technology. 20:207-220.

[9] Yang, J., Gadi, R., Paulino, R. and Thomson, T. 2010. Tota phenolics, ascorbic acid and antioxidant capacity of noni (Morinda citrifolia L.) juice and powder as affected by illumination during storage. Food Chemistry. 122:627-632.

[10] Aroldo, A-P., Fernanda, E.X.M., Abraham, D.G-Z. and Zilda, D.S.A. 2004. Vacuum drying of carrot (Daucus carota): Effects of pretreatments and parameters process. Drying 2004: Proceedings of the $14^{\text {th }}$ International Drying Symposium, August 22-25, 2004, São Paulo, Brazil. C:2021-2026.

[11] AOAC International. 1999. Official Methods of Analysis of AOAC International, $16^{\text {th }}$ ed. AOAC International, Gaithersburg, MD.

[12] James, C. 1996. Analytical chemistry of foods. London: Blackies

[13] Adriana, P.J-L., Norma, F.S-S., Rogelio, V-B., Balbina, S.S-G. and Raúl, S-C. 2010. Chemical composition, colour, and antioxidant activity of three varieties of Annona diversifolia Safford fruits. Ind. Crops Prod. doi:10.1016/j.indcrop.2010.06.012

[14] Todd, P.S. and Eric, R.J. 1998. Determining the effects of cooking on the vitamin $C$ content of green pepper. Anal 501. United States of America: Chemical Education Resources, Inc.

[15] AOAC 2000. Official Methods for Analysis, $17^{\text {th }}$ Edition. Washington DC. Association of Official Analytical Chemists.

[16] [16] Odebunmi, E.O., Oluwaniyi, O.O., Awolola, G.V. and Adediji, O.D. 2008. Proximate and nutritional composition of kola nut (Cola nitida), bitter cola (Garcinia cola) and alligator pepper (Afromomum melegueta). African Journal of Biotechnology. 8(2):308-310.

[17] James, C.S. 1999. Analytical Chemistry Of Foods. New York: Aspen Publishers. pp: 82-83.

[18] Vanderslice, J.T., Higgs, D.J., Hayes, J.M. and Block, G. 1990 Ascorbic acid and dehydroascorbic acid content of foods-as-eaten. $J$. Food Comp. Anal. 3:105-118.

[19] Tee, E.S., Mohd, I.N., Mohd, N.A. and Khatijah, I. 1997. Nutrient Composition of Malaysia Foods (Komposisi Zat Dalam Makanan Malaysia), $4^{\text {th }}$ edition. Kuala Lumpur: Malaysian Food Composition Database Programme, c/o Institute for Medical Research.

[20] Morris, A., Barnett, A. and Burrows, O-J. 2004. Effect of processing on nutrient content of foods. Cajarticles.37(3):160-164.

[21] Hasimah, H.A. 1988. Pengeringan buah-buahan. Terj. Teknologi Makanan. 7:49-53. 
[22] López-Malo, A. and Ríos-Casas, L. 2007. Solar assisted drying of foods. In Hui, Y.H., Clary, C., Farid, M.M., Fasina, O.O., Noomhorm, A. and Welti-Chanes, J. (eds.). Food Drying science and Technology: Microbiology, Chemistry, Application. United States of America: DEStech Publications, Inc, pp: 94-95.

[23] Chan, E.W.C., Lim, Y.Y., Wong, S.K., Lim, K.K., Tan, S.P., Lianto, F.S. and Yong M.Y. 2008. Effects of different drying methods on the antioxidant properties of leaves and tea of ginger species. Food Chemistry. 113:166-172.

[24] Ball, G.F.M. 2006. Vitamins in foods, analysis, bioavailability and stability. New York: CRC Taylor \& Francis.

[25] Kurimura, Y., Yokota, H. and Muraki, Y. 1981. Visible light-induced oxidation of ascorbic acid and formation of hydrogen peroxide. Bull. Chem. Soc. JPM. 54:2450-2453.
[26] Giangiacomo, A., Olesen, P.R. and Ortwerth, B.J. 1996. Ascorbic acid and glucose oxidation by ultraviolet A-generated oxygen free radicals. Investigative Ophthalmology and Visual Science. 37(8):1549-1556.

[27] Gregory, J.F. 1996. Vitamins. In Fennema, O.R. (ed.). Food Chemistry, $3^{\text {rd }}$ edition. USA: Marcel Dekker. pp:559-568.

[28] Coultate, T.P. 2002. Food - The chemistry of its components, $4^{\text {th }}$ edition. United Kingdom: The Royal Society of Chemistry. pp:281289.

[29] Belitz, H.-D., Grosch, W. and Schieberle, P. 2009. Food Chemistry ( $4^{\text {th }}$ revised and extended edition). Verlag Berlin Heidelberg: Springer. 